\title{
Acute Exacerbations of Chronic Type B Hepatitis Are Accompanied by Increased T Cell Responses to Hepatitis B Core and e Antigens
}

\author{
Implications for Hepatitis B e Antigen Seroconversion
}

\author{
S. L. Tsai," P. J. Chen," M. Y. Lai, ${ }^{\ddagger}$ P. M. Yang," J. L. Sung,* J. H. Huang, ' L. H. Hwang," T. H. Chang, and D. S. Chen* \\ ${ }^{*}$ Department of Internal Medicine, National Taiwan University Hospital, ${ }^{\ddagger}$ Graduate Institute of Clinical Medicine, \\ National Taiwan University College of Medicine and the University Hospital, and Divisions of ${ }^{\S}$ Cell Biology and Immunology and \\ "Molecular Biology, Development Center for Biotechnology, Taipei, Taiwan 10016, Republic of China
}

\begin{abstract}
T cell proliferative responses to hepatitis $B$ virus-encoded envelope antigen $\left(S+\operatorname{preS}_{2}+\right.$ preS $\left._{1}\right)$, recombinant core antigen (HBcAg), and natural hepatitis $B$ e antigen (HBeAg) were examined in $22 \mathrm{HBeAg}$-positive patients with chronic type $B$ hepatitis and 17 healthy hepatitis B surface antigen (HBsAg) carriers. The results showed that $\mathrm{HBeAg}$-positive patients had $(a)$ higher levels of $\mathrm{T}$ cell responses to $\mathrm{HBcAg} / \mathrm{HBeAg}$ than those of healthy HBsAg carriers $(P<0.001$ and $P<0.01$, respectively); (b) a further increase in these $\mathrm{T}$ cell responses during acute exacerbations $(P<0.05$ and $P<0.05$, respectively); (c) subsidence in the $\mathrm{T}$ cell responses to $\mathrm{HBcAg} / \mathrm{HBeAg}$ after recovery from acute exacerbations and $\mathrm{HBeAg}$ seroconversion, whereas the responses would persist at high levels if the patients did not enter a clinical remission; and $(d)$ low levels of $T$ cell responses to $\mathbf{S}+\operatorname{preS}_{2}+\mathrm{preS}_{1}$ either before or after HBeAg seroconversion. The appearance of increasing $T$ cell responses to $\mathrm{HBcAg} / \mathrm{HBeAg}$ usually occurred in the early phase of acute exacerbations. These findings imply that HBcAg/HBeAg-specific $T$ cells play an important role in the exacerbations of chronic hepatitis $B$ and in $\mathrm{HBeAg}$ seroconversion. $\mathrm{HBcAg} / \mathrm{HBeAg}$-specific precursor $\mathrm{T}$ cell frequencies were serially studied in selected cases by limiting dilution assay. Elevation (two- to fourfold) of $\mathrm{HBcAg} / \mathrm{HBeAg}$-specific precursor $T$ cell frequencies contributed to the increase of HBcAg/HBeAg-specific T cell proliferation during acute exacerbations. (J. Clin. Invest. 1992. 89:87-96.) Key words: hepatitis B virus • immune clearance - repertoire renewal process • tolerance
\end{abstract}

\section{Introduction}

The hepatitis B virus (HBV) ${ }^{1}$ is estimated to infect chronically more than 250 million people throughout the world and is the

Address reprint requests to Dr. Chen, Graduate Institute of Clinical Medicine, National Taiwan University College of Medicine, 1 ChangTe Street, Taipei, Taiwan 10016, Republic of China.

Received for publication 23 May 1991 and in revised form 24 September 1991 .

1. Abbreviations used in this paper: $\mathrm{Ag}$, antigen; $\mathrm{ALT}$, alanine aminotransferase; $\mathrm{CH}-\mathrm{B}$, chronic type B hepatitis; HAV, HBV, HCV, and $\mathrm{HDV}$, hepatitis A, B, C, and D viruses; similarly, $\mathrm{HBcAg}, \mathrm{HBeAg}$, and HBsAg, hepatitis B core, e, and surface antigens; likewise, anti-HAV, anti-HBc, anti-HBe, and anti-HBs, antibodies to $\mathrm{HAV}, \mathrm{HBcAg}$, $\mathrm{HBeAg}$, and $\mathrm{HBsAg}$; $\mathrm{nHBeAg}$, natural $\mathrm{HBeAg} ; \mathrm{PCR}$, polymerase chain reaction; $\mathrm{rHBcAg}$, recombinant $\mathrm{HBcAg}$; $\mathrm{SI}$, stimulation index.

J. Clin. Invest.

(c) The American Society for Clinical Investigation, Inc.

$0021-9738 / 92 / 01 / 0087 / 10 \$ 2.00$

Volume 89, January 1992, 87-96 most important etiology of cirrhosis and hepatocellular carcinoma in hyperendemic areas $(1,2)$. Patients with chronic HBV infection can be generally divided into two groups: $(a)$ those with chronic liver disease, usually referred to as having chronic type B hepatitis ( $\mathrm{CH}-\mathrm{B})$; and $(b)$ those without liver disease, referred to as being in an "inactive" or "healthy" hepatitis B surface antigen ( $\mathrm{HBsAg}$ ) carrier state (3). In addition to elevated serum alanine aminotransferase (ALT) activities and detectable $\mathrm{HBsAg}$ in serum and liver, patients with $\mathrm{CH}-\mathrm{B}$ have markers of active viral replication, such as hepatitis $B$ e antigen $(\mathrm{HBeAg})$ or $\mathrm{HBV}$ DNA in serum or hepatitis B core antigen $(\mathrm{HBcAg})$ and $\mathrm{HBeAg}$ in the liver (4). In contrast, healthy HBsAg carriers have $\mathrm{HBsAg}$ but without $\mathrm{HBV}$ DNA or $\mathrm{HBeAg}$ in serum, or detectable $\mathrm{HBcAg}$ and $\mathrm{HBeAg}$ in the liver. These carriers usually have normal serum ALT levels and no active inflammation or hepatocellular necrosis as revealed in liver biopsies (3).

Studies on the natural history of chronic HBV infection (3, $5,6)$ indicate that, except in some patients with point mutations of the pre-core (pre-C) region of the $\operatorname{HBV}$ genome $(7,8)$, these two forms probably represent two stages of chronic HBV infection. Either spontaneously or during treatment, patients with $\mathrm{CH}-\mathrm{B}$ can lose $\mathrm{HBV}$ DNA and $\mathrm{HBeAg}$ from serum and then have a remission. With subsequent appearance of antibody to $\mathrm{HBeAg}$ (anti-HBe), the disease usually evolves from chronic hepatitis to the healthy $\mathrm{HBsAg}$ carrier state. Seroconversion from $\mathrm{HBeAg}$ to anti-HBe is thus a "critical" event in the natural history of chronic HBV infection, and has been used as a major criterion for the success of interferon treatment (9).

Although the clinicopathological and virological features of $\mathrm{HBeAg}$ seroconversion are well known $(5,10-13)$, the mechanisms of the seroconversion are still unclear. Circumstantial evidence indicates that $\mathrm{HBV}$ is not directly cytopathic for the infected hepatocytes, and that HBV-induced liver cell injury is mediated by an antiviral "cellular" immune response (14-16). Because those who have cleared $\mathrm{HBeAg}$ frequently have temporary exacerbations of hepatitis before the seroconversion, it has been suggested this event represents an "immune clearance" of hepatocytes containing actively replicating $\mathrm{HBV}$ as well as $\mathrm{HBcAg} / \mathrm{HBeAg}(4,17)$. Furthermore, it has been demonstrated in a murine system that $(a)$ the production of antibody against nonparticulate $\mathrm{HBeAg}$ is helper $\mathrm{T}$ cell dependent (18), and (b) $\mathrm{HBeAg}$, the nonparticulate form of $\mathrm{HBcAg}$, is cross-reactive with $\mathrm{HBcAg}$ at the $\mathrm{T}$-cell level, but antibodies against $\mathrm{HBcAg}$ do not cross-react with $\mathrm{HBeAg}$ (19). Therefore, it is reasonable to infer that the $\mathrm{HBeAg} / \mathrm{HBcAg}$-specific $\mathrm{T}$ cells will play a key role in the modulation of acute exacerbation and $\mathrm{HBeAg}$ seroconversion. To test this hypothesis, we prospectively examined the $\mathrm{T}$ cell responses to $\mathrm{HBV}$ antigens and $\mathrm{T}$ cell precursor frequencies during acute exacerbations of $\mathrm{CH}-\mathrm{B}$. The results are then analyzed in relation to the $\mathrm{HBeAg}$ seroconversion. 


\section{Methods}

Patients. At the National Taiwan University Hospital, in November 1988, $22 \mathrm{HBeAg}$-positive patients (16 men and 6 women, mean age 35 yr) with histologically proven $\mathrm{CH}-\mathrm{B}$ were enrolled for this prospective study. 17 healthy HBsAg carriers (10 men and 7 women, mean age 33 yr) and 12 healthy volunteer adults negative for all HBV markers served as controls. Informed consent was obtained from each participant. All of the HBsAg-positive subjects had clinical follow-up every 1-3 mo. The follow-up included clinical assessment, conventional biochemical liver tests, and serological markers of viral hepatitis, including hepatitis A virus (HAV), $\mathrm{HBV}, \mathrm{C}$ virus (HCV), and D virus (HDV), as well as human immunodeficiency virus (HIV). The hepatitis A and B markers, including total or IgM anti-HAV, $\mathrm{HBsAg}$, anti-HBs, anti$\mathrm{HBc}, \mathrm{HBeAg}$, and anti-HBe, were assayed by commercially available radioimmunoassays (RIA): Havab or Havab-M, Ausria-II, Ausab, Corab, and HBeAg-RIA, respectively; Abbott Laboratories, North Chi- cago, IL. The antibody to HDV was determined in serum diluted to 1:10 by competitive solid-phase RIA (Abbott Anti-delta, Abbott Laboratories). Antibody to HCV (anti-C100-3) was detected by a commercial enzyme-linked immunosorbent assay (ELISA) (Abbott HCV Enzyme Immunoassay Diagnostic Kit, Abbott Laboratories). HIV antibody was assayed by ELISA (Enzygnost Anti-HIV Micro, Behringwerke AG, Marburg, Federal Republic of Germany). None of these patients had superinfections with HAV, HCV, HDV, or HIV. No immunosuppressive agents or antiviral therapies were given before or during the studying period (follow-up duration: $>26$ mo in all patients).

Acute exacerbations in chronic type B hepatitis were defined as episodes of abrupt elevation of ALT ( $>300 \mathrm{IU} /$ liter, normal $\leq 31 \mathrm{IU} /$ liter) with or without significant symptom aggravation. Reactivations of $\mathrm{HBV}$ in healthy HBsAg carriers were defined as reappearance of HBeAg and/or HBV DNA in the serum of a patient who was previously negative for these markers (20). Persistence of $\mathrm{HBeAg}$ after spontaneous flares was referred to as "abortive seroconversion." Clinical

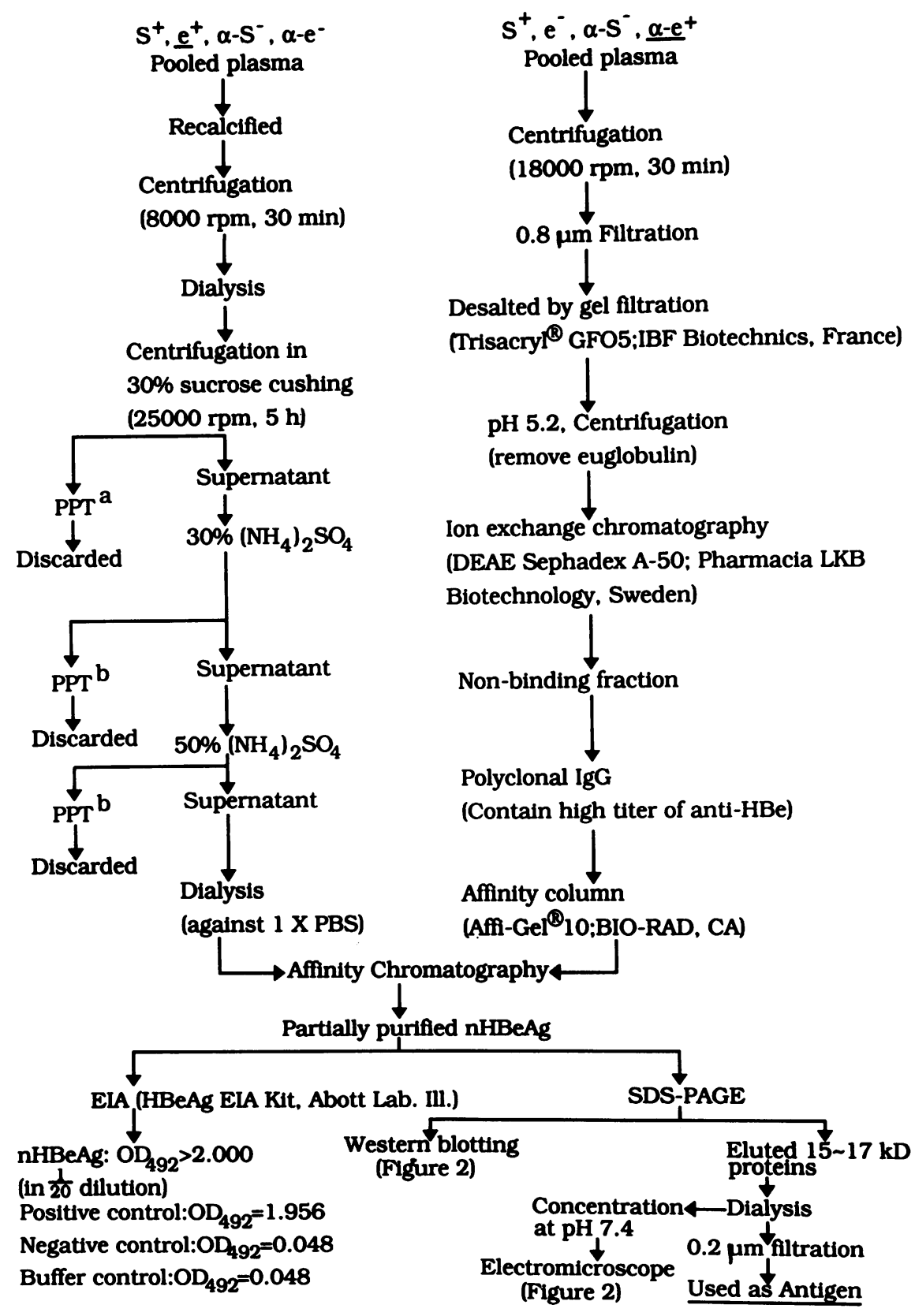

Figure 1. Flow chart showing the scheme for purification of natural $\mathrm{HBeAg}$ from plasma. S, HBsAg; e, $\mathrm{HBeAg} ; \alpha$-S, antiHBs; $\alpha$-e, anti-HBe; PPT, precipitate; a, contained Dane particles; b, $\mathrm{HBeAg}$ was still positive; PBS, phosphate-buffered saline; EIA, enzyme immunoassay. 
remissions indicated that $\mathrm{CH}-\mathrm{B}$ patients developed $\mathrm{HBeAg}$ seroconversion and normalization of liver function tests.

Detection of HBV DNA. Serum HBV DNA was detected by slot blot hybridization analysis as described previously (21).

$D N A$ sequencing of the pre-C region. In two selected patients who had frequent exacerbations with high serum HBV DNA levels after $\mathrm{HBeAg}$ clearance and seroconversion, respectively, the pre-C region of HBV genome was directly sequenced by asymmetric polymerase chain reaction (PCR) (22). The oligonucleotide primers hybridizing pre-C/ C sequences (5-GGAGGCTGTAGGCATAAATTGGTCTGCGC-3, 1776-1804) and (5-GATCTTCTGCGACGCGGCGATTGAGACC$3,2428-2401$ ) were used in the optimal ratio of 100:1. PCR was performed in a total volume of $100 \mu \mathrm{l}$. The reaction mixture contained dNTPs $200 \mu \mathrm{M}$ each, $1 \times$ Taq polymerase buffer $(67 \mathrm{mM}$ Tris, $\mathrm{pH} 8.8$, $16 \mathrm{mM}\left(\mathrm{NH}_{4}\right)_{2} \mathrm{SO}_{4}, 1.5 \mathrm{mM} \mathrm{MgCl} 2,10 \mathrm{mM}$ 2-mercaptoethanol, 6.7 $\mu \mathrm{M}$ EDTA, $170 \mu \mathrm{g} / \mathrm{ml}$ bovine serum albumin, $0.005 \%$ Tween 20 , $0.005 \%$ NP-40), and $2.5 \mathrm{U}$ of Taq polymerase (Perkin-Elmer Cetus, Norwalk, CT). 35 cycles of PCR were performed using a Perkin-Elmer Cetus apparatus, with denaturation at $94^{\circ} \mathrm{C}$, annealing of primers at $50^{\circ} \mathrm{C}$, and extension at $68^{\circ} \mathrm{C}$ for $1 \mathrm{~min}$ each. The single-strand HBV DNA of the PCR product was eluted from preparative $8 \%$ polyacrylamide gel electrophoresis (PAGE). The pre-C region was then sequenced directly by the dideoxy-chain termination method (23) with the second primer.
HBV antigens ( $\mathrm{Ag}$ ). (a) HBsAg: Plasma-derived HBsAg/adw particles were purified from $\mathrm{HBeAg}$-positive patients by immunoaffinity chromatography as described previously (24). Using mouse anti-preS and anti-preS $\mathrm{S}_{2}$ monoclonal antibodies (MAbs; Institute of Immunology Co., Tokyo) and solid-phase ELISA, levels of preS $_{1}$ and $\mathrm{preS}_{2}$ in this $\mathrm{Ag}$ preparation were about $1 \%$ and $5 \%$ of total $\mathrm{HBs} \mathrm{Ag}$ reactivity, respectively. This $\mathrm{Ag}$ was referred to as $\mathrm{S}+\mathrm{preS}_{2}+$ preS $_{1}$. (b) Recombinant (r) HBcAg: The Escherichia coli cells harboring a plasmid containing the core gene under the drive of $\lambda P_{L}$ promoter were cultured in supplemented $\mathrm{M} 9$ minimum medium at $30^{\circ} \mathrm{C}$ until the density reached $0.3-0.5$ of $\mathrm{OD}_{600}(25)$. The incubation temperature was subsequently raised to $42^{\circ} \mathrm{C}$ for $10 \mathrm{~min}$ and followed by $37^{\circ} \mathrm{C}$ for another 3 h. After induction, the cell pellet was harvested by centrifugation and dissolved in sample buffer, $\mathrm{rHBcAg}$ protein was then eluted directly from a preparative SDS-PAGE and used as antigen after dialysis. Purity of this eluted $\mathrm{rHBcAg}$ was $>98 \%$ as determined by scanning densitometry of Coomassie Blue-stained SDS-PAGE. (c) Natural (n) $\mathrm{HBeAg}$ : Because recombinant $\mathrm{HBeAg}$ is not available, we decided to use $\mathrm{nHBeAg}$ in our experiments. Consequently, we purified $\mathrm{HBeAg}$ from pooled $\mathrm{HBeAg}$-positive plasma by the method described previously (26-28) with some modifications (Fig. 1). The equivalent band in Western blot of $\mathrm{nHBeAg}(15-17 \mathrm{kD})$ protein, as shown by using mouse $\mathrm{MAb}$ against $\mathrm{HBeAg} / \mathrm{a}$ and $\mathrm{HBeAg} / \mathrm{b}$ (Institute of Immunology Co.), was then eluted directly from a preparative SDS-PAGE. After dialysis it
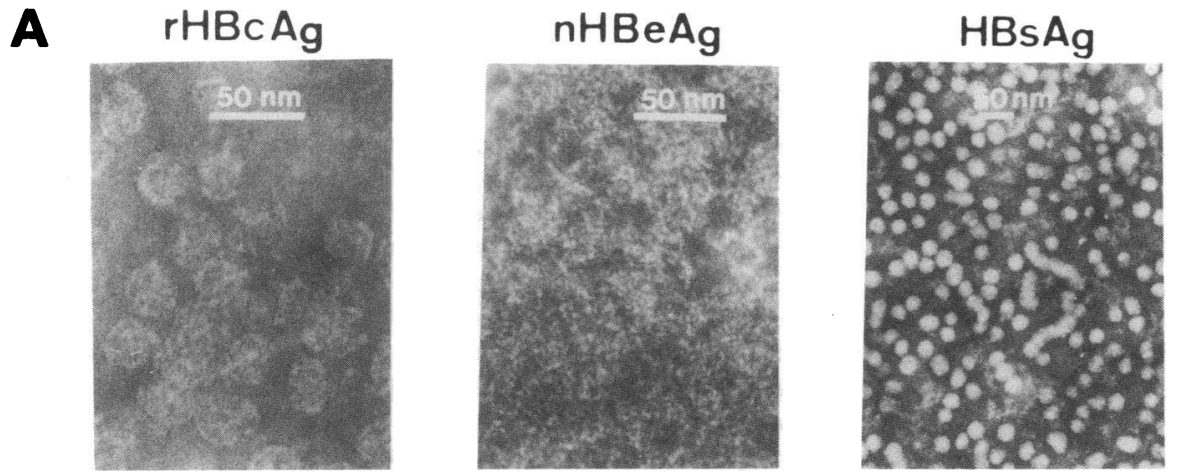

Figure 2. (A) Pictures of electron microscope, $(B)$ SDS-PAGE, and $(C)$ immunoblot analysis of hepatitis $B$ virus antigens. To purify the $\mathrm{HBcAg}$ particles, $1 \mathrm{ml}$ of $E$. coli lysate containing $\mathrm{HBcAg}$ was sedimented through $10 \mathrm{ml}$ of $5-25 \%$ of linear sucrose gradient prepared in phosphate-buffered saline. The samples were centrifuged for $5 \mathrm{~h}$ at $25,000 \mathrm{rpm}$ in an SW41 rotor (Beckman Instruments, Inc., Palo Alto, CA) at $20^{\circ} \mathrm{C}$. After centrifugation, they were collected at $1 \mathrm{ml}$ per fraction from the bottom of the tube. From each fraction, $\mathrm{HBcAg}$ was measured by enzyme im-

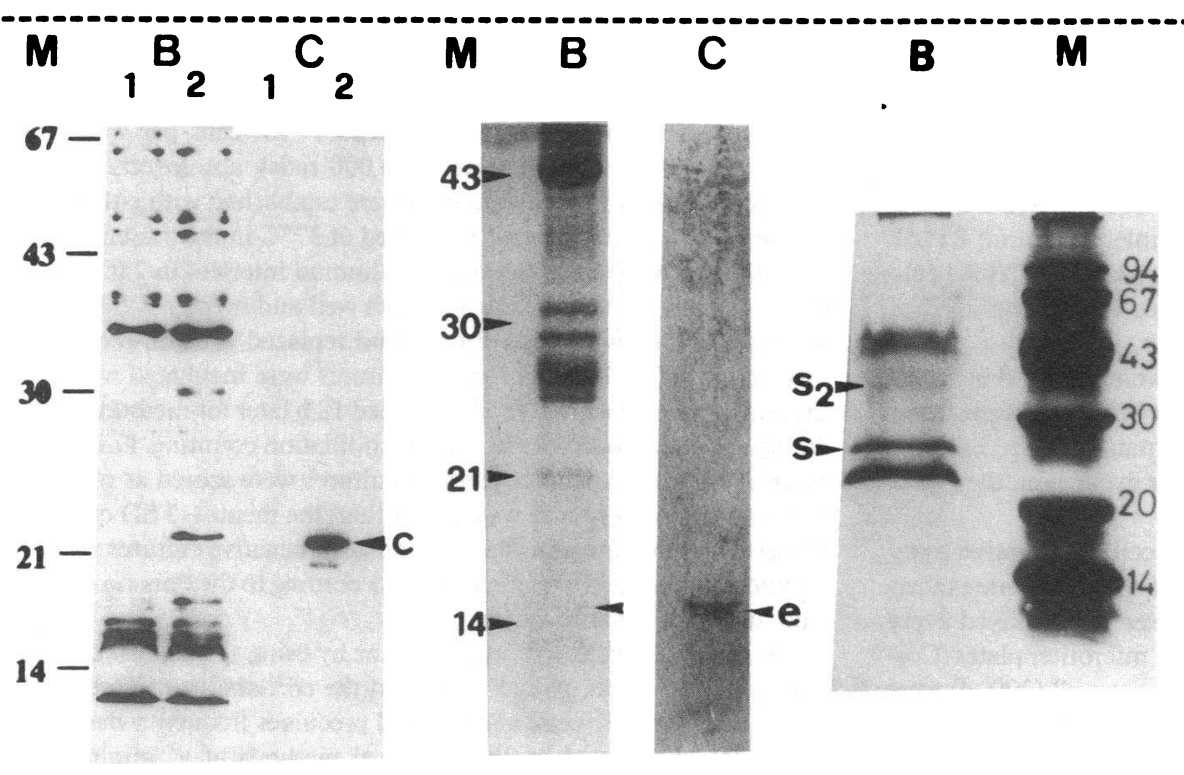
munoassay (HBeAg enzyme immunoassay Diagnostic Kit, Abbott Laboratories). Positive fractions were pooled and applied to a $17-23-29-35-41 \%$ (wt/wt) stepwise $\mathrm{CsCl}$ gradient $(2 \mathrm{ml}$ for each density) for further purification. They were centrifuged for $17 \mathrm{~h}$ at $35,000 \mathrm{rpm}$ in an $S W 41$ rotor at $20^{\circ} \mathrm{C}$, followed by collection and enzyme immunoassay as described above. The rHBcAg particles, gel-eluted $\mathrm{nHBeAg}$, and immunoaffinity-purified $\mathrm{HBsAg}$ particles $\left(\mathrm{S}+\mathrm{preS}_{2}\right.$ $+\operatorname{preS}_{1}$ ) were negatively stained with uranyl acetate. Electron micrographs were taken with a Philips EM201. Magnification: $\times 150,000$ (rHBcAg), $\times 150,000(\mathrm{nHBeAg})$, and $\times 50,000$ (HBsAg). Bar, $50 \mathrm{~nm}$. No particle was found in gel eluted nHBeAg. The SDSPAGE was performed in $12.5 \%$ for rHBcAg, $15 \%$ for $\mathrm{nHBeAg}$, and $\mathrm{HBsAg}$. The rabbit polyclonal anti-HBc and mouse monoclonal anti- $\mathrm{HBe} / \mathrm{a}+$ anti-

$\mathrm{HBe} / \mathrm{b}$ antibodies were used for Western blot analysis of rHBcAg and nHBeAg, respectively. Only SDS-PAGE with silver stain was shown for

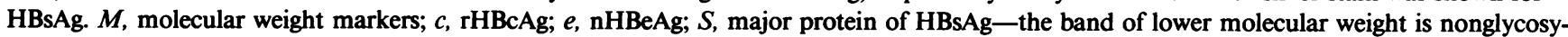
lated form of $\mathrm{HBsAg}, \mathrm{P} 24$, and the higher, glycosylated from of $\mathrm{HBsAg}, \mathrm{GP} 27 ; S_{2}$, pre $\mathrm{S}_{2}$. Lane 1, before induction; lane 2, after induction. 


\begin{tabular}{|c|c|c|c|c|c|c|}
\hline \multirow[b]{2}{*}{ Characteristics } & \multirow{2}{*}{$\begin{array}{c}\text { CH-B } \\
\text { (group a, } \\
n=22 \text { ) }\end{array}$} & \multirow{2}{*}{$\begin{array}{c}\text { Healthy } \\
\text { carrier state } \\
\text { (group b, } \\
n=17 \text { ) }\end{array}$} & \multirow{2}{*}{$\begin{array}{c}\text { Normal } \\
\text { controls } \\
\text { (group c, } \\
n=12 \text { ) }\end{array}$} & \multicolumn{3}{|c|}{$P$ value } \\
\hline & & & & a vs. b & b vs. c & a vs. c \\
\hline $\operatorname{Sex}(M / F)$ & $16 / 6$ & $10 / 7$ & $7 / 5$ & NS & NS & NS \\
\hline Age $(y r)$, mean \pm SD & $35 \pm 7$ & $33 \pm 9$ & $36 \pm 10$ & NS & NS & NS \\
\hline Serum $\mathrm{HBeAg}$ & All positive & All negative & All negative & - & - & - \\
\hline Serum HBV DNA* & All positive & All negative & All negative & - & - & - \\
\hline $\begin{array}{c}\mathrm{ALT}(\text { IU/liter }) \\
\text { mean } \pm \mathrm{SD}\end{array}$ & $158 \pm 64$ & $21 \pm 9$ & $16 \pm 8$ & $<0.001$ & NS & $<0.001$ \\
\hline $\begin{array}{l}\text { No. (\%) with positive } \\
\mathrm{T} \text { cell response to }\end{array}$ & & & & & & \\
\hline $\mathrm{S}+\mathrm{preS}_{2}+\mathrm{preS}_{1}$ & $3(13.6)$ & $1(5.9)$ & $0(0.0)$ & NS & NS & NS \\
\hline $\mathrm{rHBcAg}$ & $21(95.5)$ & $3(17.6)$ & $0(0.0)$ & $<0.001$ & NS & $<0.01$ \\
\hline nHBeAg & $19(86.4)$ & $2(11.8)$ & $0(0.0)$ & $<0.01$ & NS & $<0.01$ \\
\hline $\begin{array}{l}\text { Stimulation index } \\
\quad(\text { mean } \pm S D) \text { of }\end{array}$ & & & & & & \\
\hline $\mathrm{S}+\mathrm{preS}_{2}+\mathrm{preS}_{1}$ & $1.30 \pm 0.42$ & $1.18 \pm 0.18$ & $1.11 \pm 0.22$ & NS & NS & NS \\
\hline rHBcAg & $3.35 \pm 2.19$ & $1.53 \pm 0.58$ & $1.10 \pm 0.18$ & $<0.01$ & $<0.05$ & $<0.005$ \\
\hline nHBeAg & $3.44 \pm 2.28$ & $1.34 \pm 0.30$ & $0.99 \pm 0.23$ & $<0.001$ & $<0.005$ & $<0.001$ \\
\hline
\end{tabular}

* Detected by slot blot hybridization method.

was then used as antigen. Results of characterization of these HBV antigens are shown in Fig. 2.

Lymphocyte preparation. Peripheral blood mononuclear cells (PBMC) were prepared from fresh, heparinized blood by centrifugation on a Ficoll-Hypaque density gradient (29). Separation of T cells and non-T cells was performed by rosetting PBMC with sheep erythrocytes pretreated with 2-aminoethylisothiouronium bromide hydrobromide (Sigma Chemical Co., St. Louis, MO) (30). The E rosette-forming cells ( $T$ cells) were separated from nonrosetting cells (non-T cells) by centrifugation on the Ficoll-Hypaque density gradient. Contaminant erythrocytes were removed by hypotonic lysis with sterile distilled water. Flow cytometry analysis (FACSTAR-I, SimulSET Software Version 2.2 8/89, Becton, Dickinson \& Co., Mountain View, CA) by direct immunofluorescence with mouse MAb to Leu4 (CD3, human T cell-specific; Becton, Dickinson \& Co.) revealed that the T cell population consisted of $>95 \% \mathrm{CD}^{+}$cells (whole $\mathrm{T}$ cells), whereas the non- $\mathrm{T}$ cell fraction consisted of $<3 \% \mathrm{CD}^{+}$cells. Isolated $\mathrm{T}$ cell populations were then resuspended to $1 \times 10^{6}$ cells per $\mathrm{ml}$ in complete medium: RPMI 1640 supplemented with $25 \mathrm{mM}$ Hepes, $2 \mathrm{mM}$ L-glutamine, $10 \%$ heatinactivated human AB serum (Gibco Laboratories, Grand Island, NY), and antibiotics.

Epstein-Barr virus transformed B cell lines were prepared by incubating PBMC from six selected patients (four with $\mathrm{CH}-\mathrm{B}$ and two healthy HBsAg carriers) with the culture supernatant of the EpsteinBarr virus-producing cell, B95-8 line (31). After expansion, they were frozen in liquid nitrogen until use.

$T$ cell proliferative assay. In general, the $\mathrm{T}$ cell proliferative assay was examined every 1-3 mo. When the patients developed acute exacerbations, they were admitted and $\mathrm{T}$ cell responses were assayed every 1-2 wk. Purified T cells were cultured in 96-well microtiter plates (Costar, Cambridge, MA). Aliquots of $1 \times 10^{5}$ cells per well $(200 \mu \mathrm{l})$ were incubated in complete medium with mitomycin C-treated $(50 \mu \mathrm{g} / \mathrm{ml}$, $45 \mathrm{~min}$ at $\left.37^{\circ} \mathrm{C}\right)$ autologous non-T cells $\left(1 \times 10^{4}\right.$ cells per well $)$ which served as antigen-presenting cells. Incubation was carried out for $7 \mathrm{~d}$ at $37^{\circ} \mathrm{C}$ in a humidified $5 \% \mathrm{CO}_{2}$ atmosphere in the presence of different concentrations $(0,1.0,2.0,4.0 \mu \mathrm{g} / \mathrm{ml})$ of each of the $\mathrm{HBV} \mathrm{Ag}$ as described above. Lysate proteins from the non-rHBcAg transformant and proteins other than the $\mathrm{nHBeAg}$ from the human plasma were also included as negative controls. All proliferative assays were performed in triplicate, and $0.5 \mu \mathrm{Ci}$ per well of $\left[{ }^{3} \mathrm{H}\right]$ thymidine (sp act $2 \mathrm{Ci} / \mathrm{mmol}$; Amersham, Bucks, England) was added to each well $18 \mathrm{~h}$ before being harvested with a Skatron (Lierbyen, Norway). The data were expressed as the stimulation index ( $\mathrm{SI}=$ mean counts per minute of antigenstimulated cultures/mean counts per minute of control cultures). To examine the responsiveness, results were calculated as mean counts per minute of triplicate determinations $\left(\left[{ }^{3} \mathrm{H}\right]\right.$ thymidine incorporation). The positive response was defined as that in which the $\left[{ }^{3} \mathrm{H}\right]$ thymidine uptake was greater than the mean $+3 \mathrm{SD}$ of the control.

Precursor frequency analysis. In the six selected patients, a limiting dilution assay (LDA) with replicate cultures (sets of 24) was established in round-bottom microtiter wells. Various numbers of $T$ lymphocytes $\left(5,4,3,2,1,0.75,0.5,0.25\right.$, and $0.125 \times 10^{4}$ cells per well) were cocultured with $5 \times 10^{4}$ irradiated (8,000 rads), autologous EpsteinBarr virus B cell lines. Identical sets were established with either HBV $\mathrm{Ag}$ or controls. Cultures were incubated at $37^{\circ} \mathrm{C}$ in the presence of $5 \%$ $\mathrm{CO}_{2}$. On day 6, $20 \mathrm{U}$ of recombinant human interleukin 2 (Genzyme Corp., Boston, MA) was added to each well and on day $9,50 \%$ of the medium in each well was removed and replaced with fresh complete medium and 5\% IL-2. On day 12 , cultures were incubated with $\left[{ }^{3} \mathrm{H}\right]-$ thymidine $(1 \mu \mathrm{Ci}$ per well) and harvested $18 \mathrm{~h}$ later for measurement of incorporated radioactivity by liquid scintillation counting. For each set of 24 replicates, antigen-containing cultures were scored as positive if the proliferative response was greater than the mean $+3 \mathrm{SD}$ of control cultures without antigen. The percentage of negative cultures was used to determine the precursor frequency according to the Poisson distribution and the $\chi^{2}$ minimization (32).

Statistics. Statistic analysis was done by using $\chi^{2}$ test, Fisher's exact test, Student's $t$ test, paired $t$ test, and the correlation coefficiency for linear regression. Kinetic analysis and precursor frequency determinations were performed by the statistical methods of $\chi^{2}$ minimization (32). When the data showed $P>0.05$, the relationship between responder cell dose and the number of nonresponding wells $\left(F_{0}\right)$ was considered consistent with a single-hit kinetic model. The precursor frequency $(f)$ is equivalent to the slope of the regression line. 


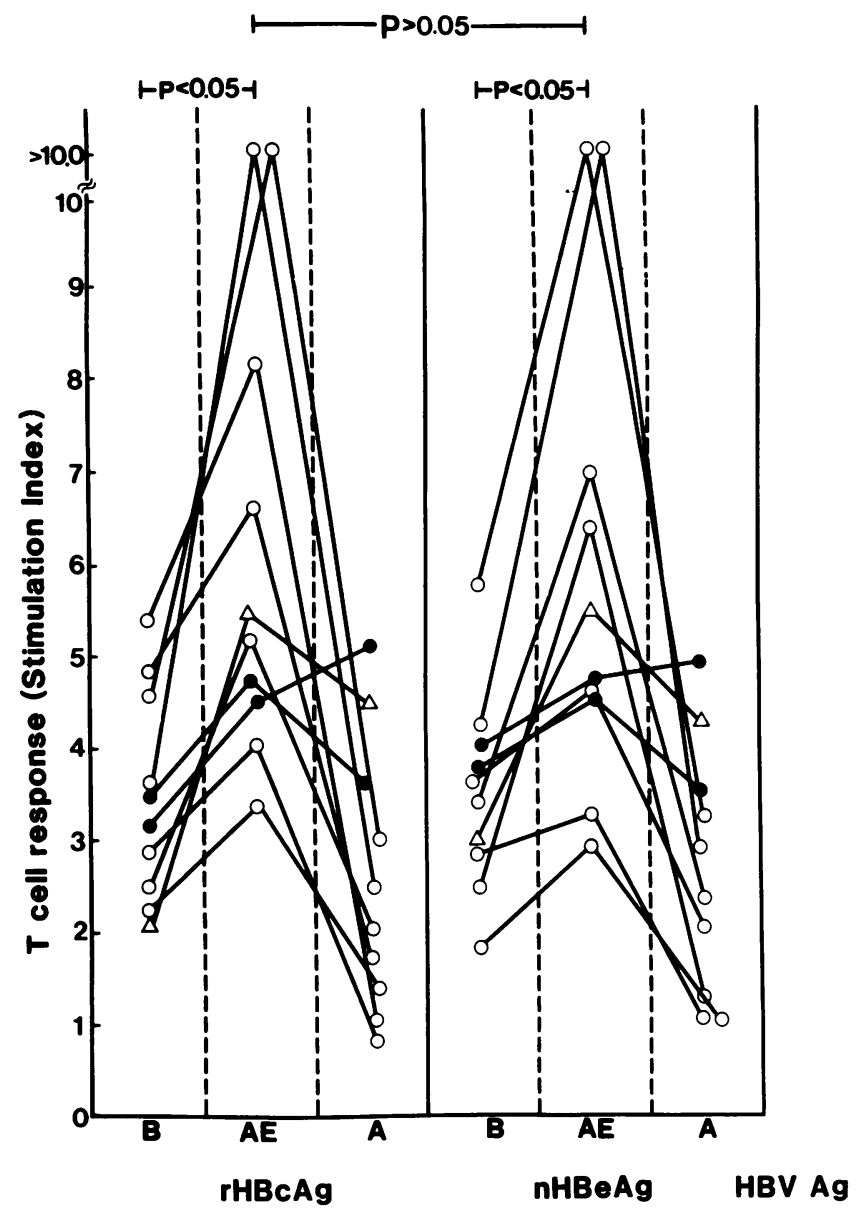

Figure 3. Follow-up study of $\mathrm{T}$ cell proliferative responses to $\mathrm{HBV} \mathrm{Ag}$ in 10 patients with $\mathrm{CH}-\mathrm{B}$ developing acute exacerbations in the follow-up period. (O) $\mathrm{HBeAg}$ seroconversion after acute episodes; (•) no $\mathrm{HBeAg}$ seroconversion; $(\triangle) \mathrm{HBeAg}$ seroclearance with no seroconversion. $A E$, acute exacerbation of $\mathrm{CH}-\mathrm{B}$ - the data represent the peak levels of $\mathrm{T}$ cell responses during $\mathrm{AE} ; B$, before $\mathrm{AE}$ - the data are results of initial examination; $A$, after $\mathrm{AE}$ - the last follow-up data.

\section{Results}

Initial study of $T$ cell proliferative responses to $H B V A g$. Table I summarizes the clinical features and the results of the initial study of $\mathrm{T}$ cell responses to $\mathrm{HBV} \mathrm{Ag}$ in chronic $\mathrm{HBV}$ infection and normal controls. Both patients with $\mathrm{CH}-\mathrm{B}$ and healthy $\mathrm{HBsAg}$ carriers uniformly showed low levels of $\mathrm{T}$ cell response to $\mathrm{S}+\mathrm{preS}_{2}+$ preS $_{1}$ (positive rates, $13.6 \%$ vs. $5.9 \% ; P>0.05$ ). The SI $\left(\right.$ mean \pm SD) to $S+$ preS $_{2}+$ preS $_{1}$ were $1.30 \pm 0.42$ and $1.18 \pm 0.18$, respectively. In contrast, $21(95.5 \%)$ and $19(86.4 \%)$ patients with CH-B, but only three (17.6\%) and two (11.8\%) healthy $\mathrm{HBsAg}$ carriers had a positive response to $\mathrm{HBCAg}$ and nHBeAg, $P<0.001$ and $P<0.01$, respectively. No statistical correlation between serum ALT levels and the SI of T cell response to either $\mathrm{rHBcAg}$ or $\mathrm{nHBeAg}$ was found (data not shown). The levels of $\mathrm{T}$ cell response to both $\mathrm{rHBcAg}$ and $\mathrm{nHBeAg}$ in CH-B patients $(\mathrm{SI}=3.35 \pm 2.19$ vs. $3.44 \pm 2.28$, $P>0.05$ ) and in healthy HBsAg carriers (SI $=1.53 \pm 0.58$ vs. $1.34 \pm 0.30, P>0.05$ ) did not have a difference in statistical significance. The SI of T cell proliferation to $S+\operatorname{preS}_{2}+\operatorname{preS}_{1}$, $\mathrm{rHBcAg}$ and $\mathrm{nHBeAg}$ of the normal controls in this study were
$1.11 \pm 0.22,1.10 \pm 0.18$, and $0.99 \pm 0.23$, respectively. Compared with normal controls, the healthy carriers of HBsAg showed no significant difference in the levels of $T$ cell proliferation to $S$ $+\operatorname{preS}_{2}+\operatorname{preS}_{1}(P>0.05)$, but still had a significant increase in $\mathrm{T}$ cell proliferation to both $\mathrm{rHBcAg}(P<0.05)$ and $\mathrm{nHBeAg}(P$ $<0.005$ ). The control cultures with eluted $E$. coli lysate proteins and background protein bands of partially purified $\mathrm{nHBeAg}$ revealed no significant $\mathrm{T}$ cell proliferation as compared with only culture medium, which can be considered to be the background $\mathrm{T}$ cell proliferation in our assay.

Follow-up study of $T$ cell proliferative responses to $\mathrm{HBV} \mathrm{Ag}$ during acute exacerbation and HBeAg seroconversion. Followup $\mathrm{T}$ cell proliferative responses to $\mathrm{HBV} \mathrm{Ag}$ were studied in all $\mathrm{CH}-\mathrm{B}$ patients and healthy $\mathrm{HBsAg}$ carriers. Of the $22 \mathrm{CH}-\mathrm{B}$ patients a total of 14 episodes ( $28 \%$ per person per year) of acute exacerbations in 10 patients was observed during the follow-up period. $8(16.2 \% / \mathrm{yr})$ of these 10 patients spontaneously underwent $\mathrm{HBeAg}$ clearance, $7(14.1 \% / \mathrm{yr})$ of them had a $\mathrm{HBeAg}$ seroconversion, and 6 also had a clinical remission. During acute exacerbations, all of these 10 patients showed a prominent increase in the peak levels of $\mathrm{T}$ cell proliferation to $\mathrm{rHBcAg}(\mathrm{SI}=6.31 \pm 2.83)$ and to $\mathrm{nHBeAg}(\mathrm{SI}=6.12 \pm 3.70)$ (Fig. 3), but not to $S+$ preS $_{2}+$ preS $_{1}(\mathrm{SI}=1.32 \pm 0.44)$. The difference of peak levels of $T$ cell responses to $\mathrm{rHBcAg}$ and $\mathrm{nHBeAg}$ was not statistically significant $(P>0.05)$. No linear correlation was noted between the peak serum ALT levels and the peak levels of $\mathrm{T}$ cell responses to $\mathrm{rHBcAg}$ or $\mathrm{nHBeAg}$ (data not shown).

In general, the onsets of peak levels of $T$ cell responses to $\mathrm{HBcAg} / \mathrm{HBeAg}$ were usually coupled with the onsets of peak serum ALT levels (Table II). However, the detectable increasing levels of the $\mathrm{HBcAg} / \mathrm{HBeAg}$-specific proliferation usually appeared before the onsets of peak serum ALT levels, i.e., occurred in the early phase of acute exacerbations. The data suggest that $\mathrm{T}$ cell responses increase at a time before or simultaneously with the hepatitis activity.

Of the 14 episodes of acute exacerbations, there was no significant difference in the peak levels of $T$ cell responses to $\mathrm{rHBcAg}$ and to $\mathrm{nHBeAg}$ between the eight episodes followed by $\mathrm{HBeAg}$ clearance and the other six episodes without $\mathrm{HBeAg}$ clearance (abortive seroconversion) (Table II).

On follow-up, those six patients (patients $1,4,5,6,7,8$; Table II) having a clinical remission also showed a significant decrease in the levels of $\mathrm{T}$ cell responses to $\mathrm{rHBcAg}$ and nHBeAg 3-6 mo after $\mathrm{HBeAg}$ seroconversion. Some of them had a decrease of $T$ cell responses down to the levels of the healthy HBsAg carriers 6-9 mo after remission from acute exacerbations. A typical case (patient 8) is depicted in Fig. 4 (top). Patients 9 and 10 remained $\mathrm{HBeAg}$ positive after acute exacerbations. Their $\mathrm{T}$ cell responses to both $\mathrm{rHBcAg}$ and $\mathrm{nHBeAg}$ persisted at high levels associated with fluctuating serum ALT levels. Despite $\mathrm{HBeAg}$ seroclearance and further follow-up for 14 mo, patient 3 (without $\mathrm{HBeAg}$ seroconversion) developed submassive hepatic necrosis with hepatic failure later. His serum HBV DNA became strongly positive as detected by slot blot hybridization. The SI of $\mathrm{T}$ cell responses to $\mathrm{S}+\mathrm{preS}_{2}$ + preS $_{1}, \mathrm{rHBcAg}$, and $\mathrm{nHBeAg}$ were 1.2, 10.6, and 9.8, respectively. Patient 2 had $\mathrm{HBeAg}$ seroconversion and had clinical remission within 3 mo after the first episode of acute exacerbation. On follow-up, he developed reactivation of HBV manifested by the reappearance of serum HBV DNA, disappearance of anti-HBe, and acute exacerbation in conjunction with an 
Table II. Timing of Detectable Increasing Levels and Peak Levels of T Cell Responses to HBcAg/HBeAg in Relation to the Onsets of Peak Serum ALT Levels during Acute Exacerbations in Patients with CH-B

\begin{tabular}{|c|c|c|c|c|}
\hline & \multicolumn{2}{|c|}{$\begin{array}{c}\text { Timing of } \mathrm{T} \text { cell responses in relation to the onsets } \\
\text { of peak ALT levels }\end{array}$} & \multicolumn{2}{|c|}{ Peak levels of $\mathrm{T}$ cell responses ${ }^{\ddagger}$} \\
\hline & $\begin{array}{l}\text { Increasing } \\
\text { levels* }\end{array}$ & Peak levels & to $\mathrm{rHBcAg}$ & to $\mathrm{nHBeAg}$ \\
\hline \multicolumn{5}{|l|}{$\begin{array}{l}\mathrm{HBeAg} \text { seroclearance } \\
\text { and/or seroconversion }\end{array}$} \\
\hline Patient 1 & 4 wk, before ${ }^{l l}$ & 1 wk, after' & 10.62 & 10.40 \\
\hline Patient $2^{\S}$ & Simultaneously & $8 \mathrm{wk}$, after & 6.60 & 6.40 \\
\hline Patient 3 & $6 \mathrm{wk}$, before & Simultaneously & 5.50 & 5.50 \\
\hline Patient 4 & Simultaneously & $8 \mathrm{wk}$, after & 4.00 & 3.25 \\
\hline Patient 5 2nd episode & 2 wk, before & $4 \mathrm{wk}$, after & 5.10 & 4.66 \\
\hline Patient 6 2nd episode & $6 \mathrm{wk}$, before & Simultaneously & 3.35 & 2.90 \\
\hline Patient 7 3rd episode & $6 \mathrm{wk}$, before & Simultaneously & 8.02 & 7.00 \\
\hline \multirow[t]{2}{*}{ Patient $8^{\S}$} & $4 \mathrm{wk}$, before & 2 wk, before & 12.00 & 12.50 \\
\hline & & & $\mathrm{Mean} \pm \mathrm{SD}=6.90 \pm 3.24^{* *}$ & $6.59 \pm 4.58^{\ddagger \ddagger}$ \\
\hline \multicolumn{5}{|c|}{$\begin{array}{l}\text { HBeAg persistent } \\
\text { (abortive seroconversion) }\end{array}$} \\
\hline Patient 9 & $2 \mathrm{wk}$, before & $3 \mathrm{wk}$, after & 4.64 & 4.75 \\
\hline Patient 10 & 2 wk, before & $4 \mathrm{wk}$, after & 4.50 & 4.50 \\
\hline Patient 5 1st episode & Simultaneously & $4 \mathrm{wk}$, after & 4.10 & 3.14 \\
\hline Patient 6 1st episode & 2 wk, before & 2 wk, after & 3.90 & 4.52 \\
\hline Patient 7 1st episode & 4 wk, before & Simultaneously & 2.98 & 3.04 \\
\hline \multirow{2}{*}{ Patient 7 2nd episode } & 1 wk, before & $1 \mathrm{wk}$, after & 6.82 & 6.40 \\
\hline & & & mean $\pm S D=4.49 \pm 1.26^{* *}$ & $4.39 \pm 1.22^{\ddagger \ddagger}$ \\
\hline
\end{tabular}

\footnotetext{
* Mean counts per minute $(\overline{\mathrm{CPM}})$ of triplicate determinations corrected for background proliferation in the absence of $\mathrm{Ag}(\Delta \overline{\mathrm{CPM}})$ is greater than $\Delta \overline{\mathrm{CPM}}+3 \mathrm{SD}$ of the lowest level stimulated with the same concentration of $\mathrm{Ag}$ before acute exacerbations.

₹ Expressed by stimulation index.

${ }^{8}$ Depicted in Fig. 4.

"Before the onset of peak serum ALT levels in acute exacerbation.

'After the onset of peak serum ALT levels in acute exacerbation.

${ }^{* *} P>0.05,{ }^{\ddagger} P>0.05$.
}

increase in $\mathrm{T}$ cell responses to $\mathrm{rHBcAg}$ and $\mathrm{nHBeAg}$ (Fig. 4, bottom). The pre-C region of $\mathrm{HBV}$ genome in these two $\mathrm{HBeAg}$-negative patients was sequenced. No point mutation at the initiation codon of the pre- $\mathrm{C}$ region was detected.

None of the 17 healthy carriers developed HBV reactivations during the follow-up period. No significant changes in $\mathrm{T}$ cell responses to $\mathrm{HBV} \mathrm{Ag}$ were detected. The healthy $\mathrm{HBsAg}$ carriers with positive $\mathrm{T}$ cell responses to $\mathrm{HBV} \mathrm{Ag}$ on initial study became unresponsive on follow-up.

HBV Ag-specific precursor $T$ cell frequency analysis. To further explore the possible mechanisms of changes in $T$ cell responses to $\mathrm{HBV} \mathrm{Ag}$ in the course of acute exacerbations, six selected cases including four $\mathrm{CH}-\mathrm{B}$ patients and two healthy carriers of HBsAg were studied by LDA to determine the HBV Ag-specific precursor $\mathrm{T}$ cell frequencies. Three of the four $\mathrm{CH}$ $B$ patients developed acute exacerbations, one of them followed by $\mathrm{HBeAg}$ seroconversion and clinical remission, whereas another patient remained unchanged in clinical status during follow-up. The two healthy $\mathrm{HBsAg}$ carriers were stable and asymptomatic and had normal liver tests on follow-up. The results of initial and follow-up LDA were shown in Table III. There was no significant difference between $\mathrm{CH}-\mathrm{B}$ patients and healthy carriers of $\mathrm{HBsAg}$ in the frequencies of $\mathrm{S}+\mathrm{preS}_{2}$ + preS $_{1}$-specific precursor $T$ cells $\left(\sim 1 / 10^{5}\right)$. However, the
$\mathrm{rHBcAg} / \mathrm{nHBeAg}$-specific precursor $\mathrm{T}$ cell frequencies of $\mathrm{CH}$ $B$ patients were significantly higher than those of healthy carriers $(P<0.05$, two-sided $t$ test performed on geometric means). During acute exacerbations, $\mathrm{rHBcAg} / \mathrm{nHBeAg}$-specific precursor $\mathrm{T}$ cell frequencies were elevated to two- to fourfold of the original levels $(P<0.01$, paired $t$ test $)$, but $\mathrm{S}+\mathrm{preS}_{2}$ + preS $_{1}$-specific precursor $\mathrm{T}$ cell frequencies remained unchanged. Fig. 5 shows the serial follow-up of standard LDA plots of case 4 in Table III. 6 mo after seroconversion to anti$\mathrm{HBe}$ and clinical remission, his $\mathrm{rHBcAg} / \mathrm{nHBeAg}$-specific precursor $\mathrm{T}$ cell frequencies decreased to two to three cells per $10^{5}$ $\mathrm{T}$ cells, approximating to the levels of healthy HBsAg carriers. Worthy of note is that $\mathrm{nHBeAg}$-specific precursor $\mathrm{T}$ cell frequencies in cases 1 and 3 were higher than $\mathrm{rHBcAg}$-specific precursor $\mathrm{T}$ cell frequencies during acute exacerbations.

\section{Discussion}

$\mathrm{T}$ cell proliferative responses to $\mathrm{HBV}$ antigens in different stages of $\mathrm{HBeAg}$-positive $\mathrm{CH}-\mathrm{B}$ were prospectively evaluated in this study. The results showed that such patients had (a) higher levels of $\mathrm{T}$ cell responses to $\mathrm{rHBcAg} / \mathrm{nHBeAg}$ than those in healthy $\mathrm{HBsAg}$ carriers, $(b)$ a further increase in T cell proliferative responses to $\mathrm{rHBcAg} / \mathrm{nHBeAg}$ during acute exacerba- 

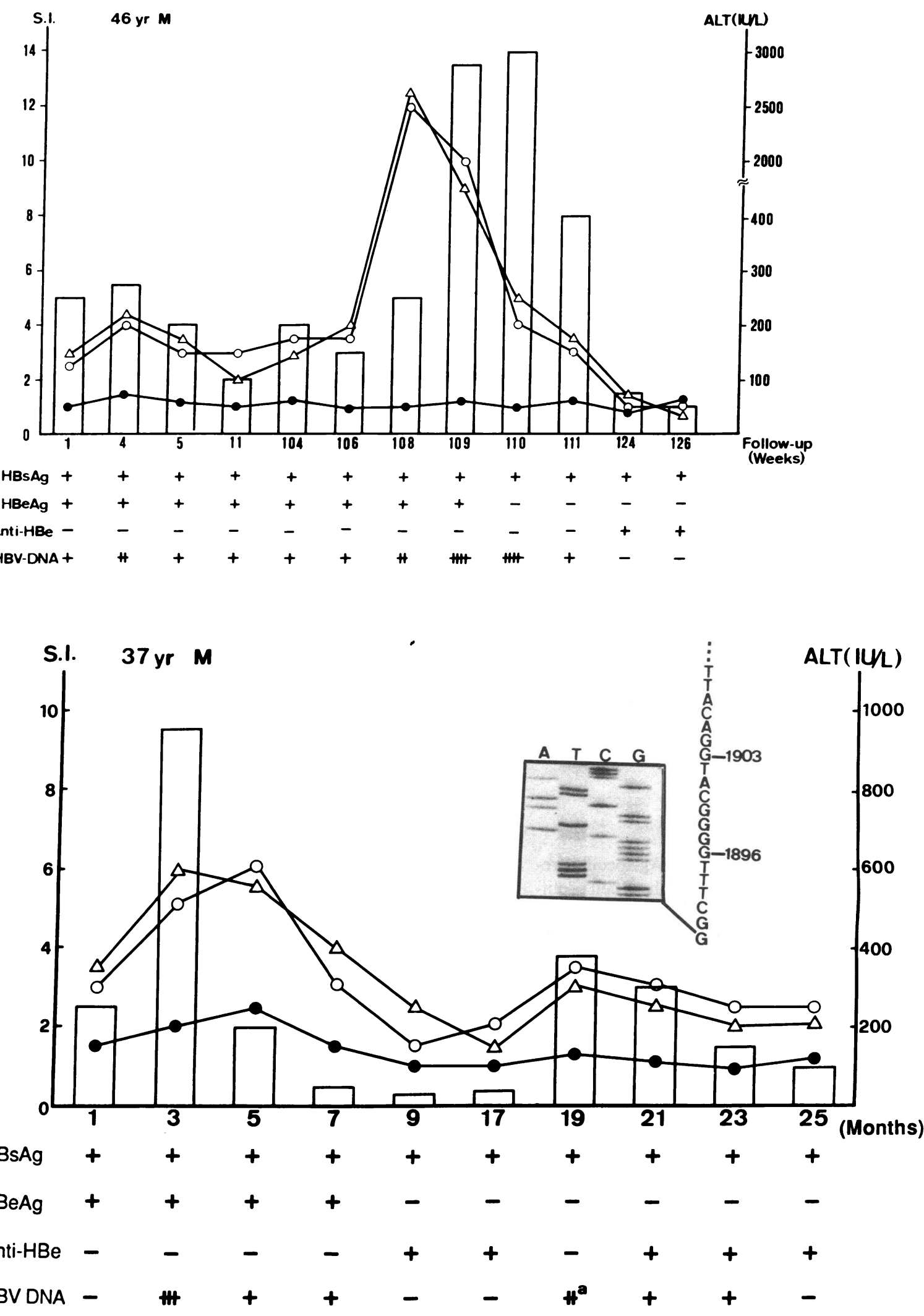

Figure 4. T cell proliferative responses to $\mathrm{HBV} \mathrm{Ag}$ in CH-B. Serial assays of the T cell responses to $1 \mu \mathrm{g} / \mathrm{ml}$ of $\mathrm{HBV}$ Ag: $\mathrm{S}+\mathrm{preS}{ }_{2}+$ preS $(\bullet)$, $\mathrm{rHBcAg}(0)$, and $\mathrm{nHBeAg}(\Delta)$ in two representative cases. (Top) A typical patient who developed acute exacerbation followed by HBeAg seroconversion and clinical remission; (bottom) $\mathrm{HBV}$ reactivation after $\mathrm{HBeAg}$ seroconversion in a man whose serum HBV DNA was extracted and pre-C region was directly sequenced by asymmetric PCR. No point mutation at nucleotide position 1896 of the pre-C region was found. Serum ALT levels were expressed by vertical open bars. ${ }^{a}$ Serum sample used for sequencing of pre-C region. The concentrations of serum HBV DNA were ranked as follows: - , undetectable;,$+ 1-10 \mathrm{pg} / \mathrm{ml} ;++, 10-100 \mathrm{pg} / \mathrm{ml} ;+++, 100-1,000 \mathrm{pg} / \mathrm{ml} ;++++,>1,000 \mathrm{pg} / \mathrm{ml}$. 
Table III. Initial and Follow-up Study of HBV Ag-specific Precursor T Cell Frequencies in Chronic HBV Infection

\begin{tabular}{|c|c|c|c|c|c|c|c|c|}
\hline \multirow[b]{2}{*}{$\begin{array}{l}\text { Case } \\
\text { no. }\end{array}$} & \multicolumn{4}{|c|}{ Initial study } & \multicolumn{4}{|c|}{ Follow-up study } \\
\hline & $\begin{array}{l}\text { Clinical } \\
\text { status }\end{array}$ & $\begin{array}{c}\text { Serum } \\
\text { HBeAg }\end{array}$ & $\begin{array}{c}\text { In vitro } \\
\text { stimulation* }\end{array}$ & $\begin{array}{c}\text { HBV Ag-specific } \\
\text { precursors per } \\
10^{5} \mathrm{~T} \text { cells } \\
(95 \% \mathrm{CL})^{\ddagger}\end{array}$ & $\begin{array}{l}\text { Clinical } \\
\text { status }\end{array}$ & $\begin{array}{l}\text { Serum } \\
\text { HBeAg }\end{array}$ & $\begin{array}{c}\text { In vitro } \\
\text { stimulation* }\end{array}$ & $\begin{array}{l}\text { HBV Ag-specific } \\
\text { precursors per } \\
10^{5} \mathrm{~T} \text { cells } \\
(95 \% \mathrm{CL})^{ \pm}\end{array}$ \\
\hline \multirow[t]{3}{*}{1} & $\mathrm{CH}-\mathrm{B}^{\S}$ & + & $\mathbf{s}$ & $1.1(0.7-1.6)$ & $\mathrm{CH}-\mathrm{B} \overline{\mathrm{c}} \mathrm{AE} \mathrm{E}^{\mathrm{I}}$ & + & $\mathbf{s}$ & $1.4(0.8-2.0)$ \\
\hline & & & c & $\underline{4.4}(3.8-6.1)$ & & & c & $\underline{7.0}(5.4-8.6)$ \\
\hline & & & e & $\underline{4.0}(3.0-5.2)$ & & & e & $\overline{7.9}(6.6-9.5)$ \\
\hline \multirow[t]{3}{*}{2} & $\mathrm{CH}-\mathrm{B}$ & + & s & $0.9(0.5-1.3)$ & $\mathrm{CH}-\mathrm{B}$ & + & s & $\overline{1.3}(0.7-2.0)$ \\
\hline & & & c & $7.1(6.0-8.2)$ & & & c & $8.2(5.9-10.5)$ \\
\hline & & & e & $8.0(6.9-9.2)$ & & & e & $8.8(6.8-10.7)$ \\
\hline \multirow[t]{3}{*}{3} & $\mathrm{CH}-\mathrm{B}$ & + & s & $1.2(0.8-1.5)$ & $\mathrm{CH}-\mathrm{B} \overline{\mathrm{c}} \mathrm{AE}$ & + & $\mathbf{s}$ & $1.5(1.0-2.0)$ \\
\hline & & & c & $\underline{3.7}(3.1-4.5)$ & & & c & $\underline{17.2}(12.0-22.4)$ \\
\hline & & & e & $\underline{4.4}(3.0-6.0)$ & & & e & $\underline{20.1}(14.8-26.4)$ \\
\hline \multirow[t]{3}{*}{4} & $\mathrm{CH}-\mathrm{B}$ & + & s & $1.0(0.7-1.3)$ & CH-B $\bar{c} \mathrm{R}^{* *}$ & - & $\mathbf{s}$ & $1.3(0.7-3.7)$ \\
\hline & & & c & $\underline{12.1}(9.0-15.0)$ & & & c & $\underline{2.7}(1.7-3.7)$ \\
\hline & & & e & $\underline{7.7}(6.7-8.7)$ & & & e & $\underline{2.1}(1.3-3.0)$ \\
\hline \multirow[t]{3}{*}{5} & $\mathrm{HC}-\mathrm{HBsAg}{ }^{\prime \prime}$ & - & $\mathbf{s}$ & $0.8(0.3-1.3)$ & & & $\mathrm{ND}^{\ddagger \ddagger}$ & \\
\hline & & & c & $2.6(1.1-3.9)$ & & & & \\
\hline & & & e & $2.0(1.0-3.0)$ & & & & \\
\hline \multirow[t]{3}{*}{6} & HC-HBsAg & - & s & $0.9(0.6-1.2)$ & & & ND & \\
\hline & & & c & $1.9(0.9-3.2)$ & & & & \\
\hline & & & e & $2.0(1.0-3.0)$ & & & & \\
\hline
\end{tabular}

Underlined values indicate significant changes in precursor $\mathrm{T}$ cell frequencies between initial and follow-up studies.

${ }^{*} \mathrm{~s}, \mathrm{~S}+\mathrm{preS}_{2}+$ preS $_{1} ; \mathrm{c}, \mathrm{rHBcAg} ; \mathrm{e}, \mathrm{nHBeAg}$.

${ }^{\ddagger} \mathrm{CL}$, confidence limits.

${ }^{8} \mathrm{CH}-\mathrm{B}$, chronic hepatitis $\mathrm{B}$.

"HC-HBsAg, healthy carrier of HBsAg.

' $\mathrm{AE}$, acute exacerbation.

** $\mathrm{R}, \mathrm{HBeAg}$ seroconversion and clinical remission.

$\ddagger \ddagger$ ND, not determined.

tions, accompanied by elevated $\mathrm{rHBcAg} / \mathrm{nHBeAg}$-specific precursor $\mathrm{T}$ cell frequencies, and $(c)$ subsidence in the $\mathrm{T}$ cell proliferative responses to $\mathrm{rHBcAg} / \mathrm{nHBeAg}$ after recovery from exacerbations and $\mathrm{HBeAg}$ seroconversion. In contrast, $\mathrm{T}$ cell proliferative responses in the presence of $\mathrm{rHBcAg} / \mathrm{nHBeAg}$ persisted at high levels if they did not reach a clinical remission from chronic active liver disease with either $\mathrm{HBeAg}$ positivity or $\mathrm{HBV}$ reactivation. On the other hand, such responses were low when tested by $S+$ preS $_{2}+$ preS $_{1}$ either before or after $\mathrm{HBeAg}$ seroconversion. These findings together with the appearance of detectable increasing levels of $T$ cell responses to $\mathrm{HBcAg} / \mathrm{HBeAg}$ usually in the early phase of acute exacerbations indicate that activation of $\mathrm{HBcAg} / \mathrm{HBeAg}$-specific $\mathrm{T}$ cells parallels with the exacerbations of $\mathrm{CH}-\mathrm{B}$ and $\mathrm{HBeAg}$ seroconversion. A similar pattern of $\mathrm{T}$ cell responses to $\mathrm{HBV} \mathrm{Ag}$ has been reported in patients with acute self-limited hepatitis B (33).

The $\mathrm{T}$ cell responses are similar when evaluated by $\mathrm{rHBcAg}$ or $\mathrm{nHBeAg}$ in different stages of chronic HBV infection, suggesting that $\mathrm{HBeAg}$ in humans is also cross-reactive with $\mathrm{HBcAg}$ at the $\mathrm{T}$ cell level, as has been found in the murine system $(16,19)$.

In Taiwan, a hyperendemic area of $\mathrm{HBV}$ infection, the vast majority of patients with $\mathrm{HBeAg}$-positive $\mathrm{CH}-\mathrm{B}$ were born to $\mathrm{HBeAg}$-positive mothers and infected in the neonatal or perinatal period at that time their $\mathrm{T}$ cells were probably tolerant to
$\mathrm{HBeAg}$ (34). Milich and co-workers (35) have suggested that "HBeAg," a secreted protein, may cross the placenta and circulate to the fetal thymus where through a mechanism of thymic education leads to the functional deletion or inactivation of major histocompatibility complex class II-restricted helper T cells in utero resulting in host tolerance specific for the $\mathrm{HBcAg} /$ $\mathrm{HBeAg}$. But the $\mathrm{HBcAg} / \mathrm{HBeAg}$-specific host tolerance is reversible. In the absence (or decrease in the level) of tolerogen (i.e., $\mathrm{HBeAg}$ ), new $\mathrm{HBcAg} / \mathrm{HBeAg}$-specific thymocytes can emerge from the thymus, and this $\mathrm{HBcAg} / \mathrm{HBeAg}$-specific $\mathrm{T}$ cell "repertoire renewal process" requires $\sim 13-16$ wk in the murine model. In humans, we propose that once the level of $\mathrm{HBeAg}$ (tolerogen) declines to a threshold not sufficient to maintain the tolerance status, the $\mathrm{HBcAg} / \mathrm{HBeAg}$-specific $\mathrm{T}$ cell repertoire renewal process may be initiated even in the presence of $\mathrm{HBeAg}$. Indeed, it is during the low replicative phase when the $\mathrm{HBeAg}$ (tolerogen) levels are lowering, the $\mathrm{CH}$ $B$ patients are attacked by a series of relapses and remissions associated with histologic signs of chronic active liver disease $(10,11)$. Milich et al. (36) have recently demonstrated that in the murine transgenic model, "quiescent" $\mathrm{HBeAg}$-specific helper $T$ cells can be reactivated by a single injection of the synthetic $T$ cell site e129-140, resulting in a rapid, transient seroconversion to anti-HBe. Both the hypothesis of repertoire renewal process and the phenomenon of reactivation of quiescent $\mathrm{HBeAg}$-specific $\mathrm{T}$ helper cells can be supported by our 


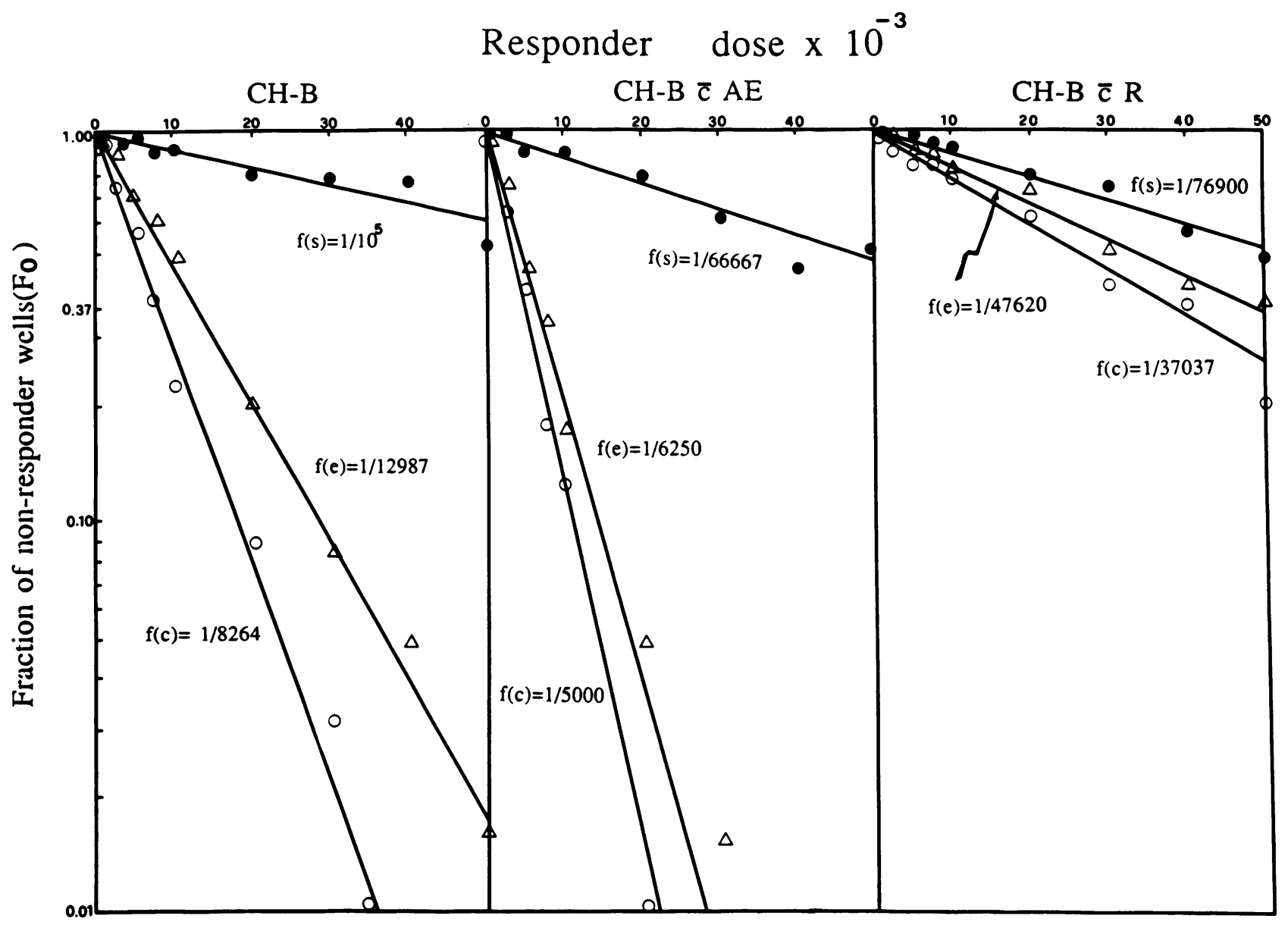

Figure 5. Serial follow-up study of HBV Ag-specific precursor T cell frequencies of case 4 in Table III. CH-B, chronic type B hepatitis; $A E$, acute exacerbation; $R, \mathrm{HBeAg}$ seroconversion and clinical remission.

study that acute exacerbation in $\mathrm{CH}-\mathrm{B}$ is temporally correlated with the elevated $\mathrm{T}$ cell responses to $\mathrm{rHBcAg} / \mathrm{nHBeAg}$ and with the increase of $\mathrm{rHBcAg} / \mathrm{nHBeAg}$-specific precursor $\mathrm{T}$ cell frequencies.

Compatible with the results from the study using recombinant $\mathrm{HBeAg}$ in acute and chronic hepatitis $\mathrm{B}(33)$, the levels of $T$ cell responses to $\mathrm{nHBeAg}$ were also slightly lower than to $\mathrm{rHBcAg}$ during acute exacerbations in $\mathrm{CH}-\mathrm{B}$. The reasons may be due to the conformational features of $\mathrm{rHBcAg}$, which could be more efficiently internalized and then presented by antigenpresenting cells (18), and partly due to the presence of $\mathrm{HBcAg}$ specific $T$ cell epitopes within the 39 amino acids unique for $\mathrm{HBcAg}$ at the carboxyl terminus. Nevertheless, some patients had higher levels of $\mathrm{T}$ cell responses to $\mathrm{nHBeAg}$ than to $\mathrm{rHBcAg}$ and have more prominent increase in the $\mathrm{nHBeAg}$ specific precursor $\mathrm{T}$ cell frequencies than that of $\mathrm{rHBcAg}$. This suggests that the additional $10 \mathrm{NH}_{2}$-terminal amino acids present only within the $\mathrm{nHBeAg}(37,38)$ probably contain an $\mathrm{HBeAg}$-specific $\mathrm{T}$ cell epitope and can contribute to the antigen recognition by $\mathrm{T}$ cells during the course of $\mathrm{HBeAg}$ seroconversion.

After $\mathrm{HBeAg}$ seroconversion, most patients with $\mathrm{CH}-\mathrm{B}$ will resolve into healthy $\mathrm{HBsAg}$ carrier state. No more active $\mathrm{HBV}$ replication is detected and the $\mathrm{T}$ cell responses to $\mathrm{rHBcAg} / \mathrm{nH}$ $\mathrm{BeAg}$ will decline gradually to a level equivalent to that in healthy HBsAg carriers. However, despite seroconversion, there is one group of patients whose hepatitis continues to progress, accompanied by high levels of HBV DNA in the serum (39). Carman et al. (7) demonstrated a point mutation $(G \rightarrow A)$ at nucleotide 1896 in the pre-C region of $\mathrm{HBV}$ genome precluding secretion of $\mathrm{HBeAg}$ in seven out of eight patients with anti-HBe-positive $\mathrm{CH}-\mathrm{B}$. In the present study, one patient with active $\mathrm{HBV}$ replication after $\mathrm{HBeAg}$ seroconversion, and another in the window period, were examined for their pre-C sequences. No point mutation at position 1896 was found. Therefore, after $\mathrm{HBeAg}$ seroconversion it is not known whether anti-HBe-positive patients with point mutations at pre-C region of HBV genome have the same patterns of $T$ cell responses to $\mathrm{HBV}$ antigens as those without pre-C point mutation. Additional studies are apparently needed.

Although increased $\mathrm{HBcAg} / \mathrm{HBeAg}$-specific $\mathrm{T}$ cell responses are closely related to hepatitis activity, the mechanism responsible for exacerbation of $\mathrm{CH}-\mathrm{B}$ is not yet settled. It is necessary to study whether or not there is increase in the $\mathrm{HBcAg} / \mathrm{HBeAg}$-specific $\mathrm{T}$ cell population in the liver. In fact, Ferrari and co-workers (40) isolated lymphocytes from diagnostic liver biopsies of $\mathrm{CH}-\mathrm{B}$ patients and successfully established and characterized polyclonal $\mathrm{HBcAg}$-specific $\mathrm{CD}^{+}$and $\mathrm{CD}^{+} \mathrm{T}$ cell lines; but no $\mathrm{HBsAg}$-specific cell lines could be identified. It implies that these intrahepatic nucleocapsid Agspecific $T$ cells may be responsible for mediating hepatitis activities, and very likely reflects in the increased $\mathrm{T}$ cell responses to 
$\mathrm{rHBcAg} / \mathrm{nHBeAg}$ in the peripheral blood. They have subsequently cloned one of these lines to produce four $\mathrm{CD} 4^{+} \mathrm{T}$-cell clones that undergo class II-restricted proliferation in response to $\mathrm{HBcAg}$ and are capable of providing antigen-specific help to autologous B cells producing anti-HBc (41). However, whether or not these $\mathrm{HBcAg}$-specific $\mathrm{T}$ cell clones are cross-reactive with the natural $\mathrm{HBeAg}$ and are able to provide an antigen-specific help to produce anti-HBe has not yet been clarified. Thus, to explore further the immune mechanisms of $\mathrm{HBeAg}$ seroconversion in chronic $\mathrm{HBV}$ infection, functional studies of $\mathrm{HBcAg} / \mathrm{HBeAg}$-specific $\mathrm{T}$ cell clones generated from the inflammatory infiltrate in the liver and analysis of their fine specificities as well as $\mathrm{T}$ cell receptor gene usages are ongoing in our laboratories.

\section{Acknowledgments}

We are grateful to Miss M. S. Chuang for expert secretarial assistance.

This work is supported in part by grants from the Department of Health, the National Science Council, Executive Yuan, and Institute of Biomedical Sciences, Academia Sinica, Republic of China.

\section{References}

1. Beasley, R. P., C. C. Lin, L. Y. Hwang, and C. S. Chien. 1981. Hepatocellular carcinoma and hepatitis B virus: a prospective study of 22,707 men in Taiwan. Lancet. ii:1129-1133.

2. Popper, H., D. A. Schafritz, and J. H. Hoofnagle. 1987. Relation of hepatitis B virus carrier state to hepatocellular carcinoma. Hepatology. 7:764-772.

3. Hoofnagle, J. H., D. A. Schafritz, and H. Popper. 1987. Chronic type B hepatitis and the "healthy" HBsAg carrier state. Hepatology. 7:758-763.

4. Mondelli, M., R. S. Tedder, B. Ferns, P. Pontisso, G. Realdi, and A. Alberti. 1986. Differential distribution of hepatitis B core and e antigens in hepatocytes: analysis by monoclonal antibodies. Hepatology. 6:199-204.

5. Hoofnagle, J. H. 1983. Chronic type B hepatitis (editorial). Gastroenterology. 84:422-423.

6. Chu, C. M., P. Karayiannis, M. J. F. Fowler, J. Monjardino, Y. F. Liaw, and H. C. Thomas. 1985. Natural history of chronic hepatitis B virus infection in Taiwan: studies of hepatitis B virus DNA in serum. Hepatology. 5:431-434.

7. Carman, W. F., M. R. Jacyna, S. Hadziyannis, P. Karayiannis, M. J. McGarvey, A. Makris, and H. C. Thomas. 1989. Mutation preventing formation of hepatitis B e antigen in patients with chronic hepatitis B infection. Lancet. ii:588-591.

8. Akahane, Y., T. Yamanaka, H. Suzuki, Y. Sugai, F. Tsuda, S. Yotsumoto, S. Omi, H. Okamoto, Y. Miyakawa, and M. Mayumi. 1990. Chronic active hepatitis with hepatitis B virus DNA and antibody against e antigen in serum: disturbed synthesis and secretion of e antigen from hepatocytes due to a point mutation in the precore region. Gastroenterology. 99:1113-1119.

9. Perillo, R. P., E. R. Schiff, G. L. Davis, Jr., H. C. Bodenheimer, K. Lindsay, J. Payne, J. L. Dienstag, C. O'Brien, C. Tamburro, I. M. Jacobson, et al. 1990. A randomized, controlled trial of interferon alfa- $2 \mathrm{~b}$ alone and after prednisolone withdrawal for the treatment of chronic hepatitis B. N. Engl. J. Med. 323:295301 .

10. Liaw, Y. F. 1986. Natural history of chronic hepatitis B virus infection. In Chronic Hepatitis. Y. F. Liaw, editor. Elsevier/North Holland, Amsterdam. 9-18.

11. Chen, D. S., and J. L. Sung. 1987. Hepatitis B e antigen and its antibody in chronic type B hepatitis. J. Gastroenterol. Hepatol. 2:255-270.

12. Su, I. J., M. Y. Lai, H. C. Hsu, D. S. Chen, P. M. Yang, and J. L. Sung. 1986. Diverse virologic, histopathologic and prognostic implications of seroconversion from $\mathrm{HBeAg}$ to anti-HBe in chronic hepatitis B virus infection. J. Hepatol. 3:182-189.

13. Lee, P. I., M. H. Chang, C. Y. Lee, H. Y. Hsu, J. S. Chen, P. J. Chen, and D. S. Chen. 1990. Changes of serum hepatitis B virus DNA and aminotransferase levels during the course of chronic hepatitis B virus infection in children. Hepatology. 12:657-660.

14. Mills, C. T., E. Lee, and R. Perrillo. 1990. Relationship between histology, aminotransferase levels, and viral replication in chronic hepatitis B. Gastroenterology. 99:519-524.

15. Chisari, F. V., C. Ferrari, and M. U. Mondelli. 1989. Hepatitis B virus structure and biology. Microb. Pathog. 6:311-325.

16. Milich, D. R. 1991. Immune response to hepatitis B virus proteins: relevance of the murine model. Semin. Liver Dis. 11:93-112.
17. Chu, C. M., and Y. F. Liaw. 1990. Intrahepatic expression of HBcAg in chronic HBV hepatitis: lessons from molecular biology (hepatology elsewhere). Hepatology. 12:1443-1445.

18. Milich, D. R., A. McLachlan, S. Stahl, P. Wingfield, G. B. Thornton, J. L. Hughes, and J. E. Jones. 1988. Comparative immunogenicity of hepatitis B virus core and e antigens. J. Immunol. 141:3617-3624.

19. Milich, D. R., A. McLachlan, A. Moriarty, and G. B. Thornton. 1987. Immune response to hepatitis $B$ virus core antigen $(\mathrm{HBcAg})$ : localization of $\mathrm{T}$ cell recognition sites within $\mathrm{HBcAg} / \mathrm{HBeAg}$. J. Immunol. 139:1223-1231.

20. Davis, G. L., J. H. Hoofnagle, and J. G. Waggoner. 1984. Spontaneous reactivation of chronic hepatitis B virus infection. Gastroenterology. 86:230-235.

21. Chen, D. S., M. Y. Lai, S. C. Lee, P. M. Yang, J. C. Sheu, and J. L. Sung. 1986. Serum $\mathrm{HBsAg}, \mathrm{HBeAg}$, anti-HBe and hepatitis B virus DNA in asymptomatic carriers in Taiwan. J. Med. Virol. 19:87-94.

22. Brow, M. A. D. 1990. Sequencing with Taq DNA polymerase. In PCR Protocols. A Guide to Methods and Applications. M. A. Innis, D. H. Gelfand, J. J. Sninsky, and T. J. White, editors. Academic Press/California, San Diego. 189-196.

23. Sanger, F., S. Nicklen, and A. R. Coulson. 1977. DNA sequencing with chain terminating inhibitors. Proc. Natl. Acad. Sci. USA. 74:5463-5467.

24. Sheu, W. J., H. H. Yang, Z. T. Wu, C. C. Lin, C. H. Chiou, J. H. Huang, J. H. Hsieh, M. Shiang, C. C. Chang, S. C. Shih, et al. 1990. Generation of HBsAg-specific $\mathrm{T}$ cell clones using immuno-affinity purified plasma and recombinant S and pre-S antigens. In Viral Hepatitis and Hepatocellular Carcinoma. J. L. Sung and D. S. Chen, editors. Excerpta Medica/Asia, Hong Kong. 117-124.

25. Hwang, L. H., B. F. Chen, H. M. Lin, L. L. Soong, Y. S. Jou, W. C. Chang, and S. T. Liu. 1990. The striking effects of spacer and terminator sequences on the synthesis of porcine growth hormone in Escherichia coli. Biotechnol. Lett. 12:335-340.

26. Fields, H. A., D. W. Bradley, C. L. Davis, and J. E. Maynard. 1978. Purification and partial characterization of hepatitis e antigen $(\mathrm{HBeAg})$. Infect. Immun. 20:792-803.

27. Takahashi, K., M. Imai, T. Gotanda, T. Sano, A. Oinuma, S. Mishiro, Y. Miyakawa, and M. Mayumi. 1980. Hepatitis B e antigen polypeptides isolated from sera of individuals infected with hepatitis $B$ virus: comparison with $\mathrm{HBeAg}$ polypeptides derived from Dane particles. J. Gen. Virol. 50:49-57.

28. Matsuda, K., A. Kanno, and H. Ohori. 1986. Immunochemical characterization of hepatitis $B$ e antigen subtypes, $\mathrm{HBeAg} / 1$ and $\mathrm{HBeAg} / 2$, in sera of hepatitis B virus carriers. J. Med. Virol. 20:219-228.

29. Böyum, A. 1968. Separation of leucocytes from blood and bone marrow. Scand. J. Clin. Lab. Invest. 21(Suppl. 97):77-81.

30. Saxon, A., J. Feldhaus, and R. A. Robins. 1976. Single step separation of human $\mathrm{T}$ and B cells using AET treated SRBC rosettes. J. Immunol. Methods. 12:285-288.

31. Miller, G., and M. Lipman. 1973. Release of infectious Epstein-Barr virus by transformed marmoset leucocytes. Proc. Natl. Acad. Sci. USA. 70:190-194.

32. Taswell, C. 1981. Limiting dilution assays for the determination of immunocompetent cell frequencies. I. Data analysis. J. Immunol. 126:1614-1619.

33. Ferrari, C., A. Penna, A. Bertoletti, A. Valli, A. Degli-Antoni, T. Giuberti, A. Cavalli, M-A. Petti, and F. Fiaccadori. 1990. Cellular immune response to hepatitis B virus-encoded antigens in acute and chronic hepatitis B virus infection. J. Immunol. 145:3442-3449.

34. Chen, D. S. 1987. Hepatitis B virus infection, its sequelae, and prevention in Taiwan. In Neoplasms of the Liver. K. Okuda and K. G. Ishak, editors Springer-Verlag/Asia, Tokyo. 71-80.

35. Milich, D. R., J. E. Jones, J. L. Hughes, J. Price, A. K. Raney, and A. McLachlan. 1990. Is a function of the secreted hepatitis B e antigen to induce immunologic tolerance in utero? Proc. Natl. Acad. Sci. USA. 87:6599-6603.

36. Milich, D. R., A. McLachlan, A. K. Raney, R. Houghten, G. B. Thornton, T. Maruyama, J. L. Hughes, and J. E. Jones. 1991. Autoantibody production in hepatitis B e antigen transgenic mice elicited with a self $\mathrm{T}$-cell peptide and inhibited with nonself peptides. Proc. Natl. Acad. Sci. USA. 88:4348-4352.

37. Takahashi, K., A. Machida, G. Funatsu, M. Nomura, S. Usuda, S. Aoyagi, K. Tachibana, H. Miyamoto, M. Imai, T. Nakamura, et al. 1983. Immunochemical structure of hepatitis B e antigen in the serum. J. Immunol. 130:2903-2907.

38. Gerlich, W. H., and V. Bruss. 1988. Formation of transmembraneous hepatitis B e antigen by cotranslational in vitro processing of the viral precore protein. Virology. 163:268-275.

39. Hadziyannis, S. J., H. M. Lieberman, G. G. Karvountzis, and D. A. Shafritz. 1983. Analysis of liver disease, nuclear $\mathrm{HBcAg}$, viral replication, and hepatitis $B$ virus DNA in liver and serum of $\mathrm{HBeAg}$ vs. anti-HBe positive carriers of hepatitis B virus. Hepatology. 3:656-662.

40. Ferrari, C., A. Penna, T. Giuberti, M. J. Tong, E. Ribera, F. Fiaccadori, and F. V. Chisari. 1987. Intrahepatic, nucleocapsid antigen-specific $T$ cells in chronic active hepatitis B. J. Immunol. 139:2050-2058.

41. Ferrari, C., M. U. Mondelli, A. Penna, F. Fiaccadori, and F. V. Chisari. 1987. Functional characterization of cloned intrahepatic hepatitis B virus nucleoprotein-specific helper T cell lines. J. Immunol. 139:539-544. 